\title{
Non-aneurysmal subarachnoid haemorrhage in COVID-19—authors' reply to Kawada T
}

\author{
Suzanne Harrogate ${ }^{1} \cdot$ Alex Mortimer $^{1} \cdot$ Lorna Burrows $^{1} \cdot$ Barnaby Fiddes $^{1} \cdot$ Ian Thomas $^{1} \cdot$ Claire M. Rice $^{1,2}$ (I)
}

Received: 29 March 2021 / Accepted: 4 April 2021 / Published online: 17 April 2021

(c) The Author(s), under exclusive licence to Springer-Verlag GmbH Germany, part of Springer Nature 2021

\section{Dear Editor:}

We are grateful to Dr. Kawada for highlighting additional cases of non-aneurysmal subarachnoid haemorrhage (SAH) which have occurred in the context of severe coronavirus disease 2019 (COVID-19). Indeed, several additional case series have recently been published, including those with pathological findings [1-3], and we anticipate that additional cases of CNS haemorrhagic complications of COVID-19 infection will be reported in emerging registry data.

Although we wish to raise awareness of the risk of SAH in COVID-19, we consider that, for the majority of patients, thrombosis is likely to present a greater risk [4]. However, while early use of prophylactic anticoagulation was associated with lower mortality without an increase in morbidity in a large observational study [5], recruitment to clinical trials of therapeutic anticoagulation in those requiring intensive care unit support has been halted [6]. It remains to be determined, whether immunomodulatory treatment alters the risk of thrombosis and haemorrhage in patients with severe COVID-19 [7].

Until best practice is determined definitively and predication of individual risk improved, we strongly recommend that centres follow credible guidelines such as those issued by the National Institute for Health and Care Excellence (NICE) [8], the International Society on Haemostasis and Thrombosis [9] and the American Society of Hematology [10], with standardised reporting of both thrombotic and

This is a letter reply to the original article https://doi.org/10.1007/ s00234-020-02535-4 and Letter to the Editor https://doi.org/10. 1007/s00234-021-02700-3.

Claire M. Rice

c.m.rice@bristol.ac.uk

1 North Bristol NHS Trust, Southmead Hospital, Bristol, UK

2 Translational Health Sciences, Bristol Medical School, University of Bristol, Bristol, UK haemorrhagic events occurring in the context of COVID-19 infection.

\section{Declarations}

Conflict of interest The authors declare that they have no conflict of interest.

Ethical approval No human participants.

Informed consent No human participants.

\section{References}

1. Büttner L, Bauknecht HC, Fleckenstein FN, Kahn J, Tietze A, Bohner G, Siebert E (2021) Neuroimaging findings in conjunction with severe COVID-19. Rofo. https://doi.org/10. 1055/a-1345-9784

2. Pajo AT, Espiritu AI, Apor ADAO, Jamora RDG (2021) Neuropathologic findings of patients with COVID-19: a systematic review. Neurol Sci 42(4):1255-1266. https://doi.org/10.1007/ s10072-021-05068-7

3. Sawlani V, Scotton S, Nader K, Jen JP, Patel M, Gokani K, Denno P, Thaller M, Englezou C, Janjua U, Bowen M, Hoskote C, Veenith T, Hassan-Smith G, Jacob S (2021) COVID-19-related intracranial imaging findings: a large single-centre experience. Clin Radiol 76(2):108-116. https://doi.org/10.1016/j.crad.2020. 09.002

4. Malas MB, Naazie IN, Elsayed N, Mathlouthi A, Marmor R, Clary B (2020) Thromboembolism risk of COVID-19 is high and associated with a higher risk of mortality: a systematic review and meta-analysis. EClinicalMedicine 29:100639. https://doi.org/10. 1016/j.eclinm.2020.100639

5. Rentsch CT, Beckman JA, Tomlinson L, Gellad WF, Alcorn C, Kidwai-Khan F, Skanderson M, Brittain E, King JT, Ho YL, Eden S, Kundu S, Lann MF, Greevy RA, Ho PM, Heidenreich PA, Jacobson DA, Douglas IJ, Tate JP, Evans SJW, Atkins D, Justice AC, Freiberg MS (2021) Early initiation of prophylactic anticoagulation for prevention of coronavirus disease 2019 mortality in patients admitted to hospital in the United States: cohort study. BMJ 372:n311. https://doi.org/10.1136/bmj.n311 
6. The REMAP-AP, ACTIV-4a, ATTACC Investigators, Zarychanski R (2021) Therapeutic anticoagulation in critically ill patients with COVID-19 - preliminary report. MedRxiv. https://doi.org/ 10.1101/2021.03.10.21252749

7. Mehta P, Haskard DO, Laffan MA, Chambers RC, Hunt BJ (2021) Thromboses and COVID-19: reducing inflammation in addition to thromboprophylaxis. Lancet Rheumatol 3(3):e171-e172. https:// doi.org/10.1016/S2665-9913(21)00003-5

8. National Institute for Health and Clinical Care (NICE; NG191) (2021) COVID-19 rapid guideline: managing COVID-19. https:// www.nice.org.uk/guidance/ng191/resources/covid19-rapid-guide line-managing-covid19-pdf-66142077109189 Accessed 26 March 2021

9. Spyropoulos AC, Levy JH, Ageno W, Connors JM, Hunt BJ, Iba T, Levi M, Samama CM, Thachil J, Giannis D, Douketis JD, Subcommittee on Perioperative CCT, Haemostasis of the Scientific, Standardization Committee of the International Society on Thrombosis and Haemostasis (2020) Scientific and Standardization Committee communication: clinical guidance on the diagnosis, prevention, and treatment of venous thromboembolism in hospitalized patients with COVID-19. J Thromb Haemost 18(8):1859-1865. https://doi.org/10.1111/jth.14929

10. Cuker A, Tseng EK, Nieuwlaat R, Angchaisuksiri P, Blair C, Dane K, Davila J, DeSancho MT, Diuguid D, Griffin DO, Kahn SR, Klok FA, Lee AI, Neumann I, Pai A, Pai M, Righini M, Sanfilippo KM, Siegal D, Skara M, Touri K, Akl EA, BouAkl I, Boulos M, Brignardello-Petersen R, Charide R, Chan M, Dearness K, Darzi AJ, Kolb P, Colunga-Lozano LE, Mansour R, Morgano GP, Morsi RZ, Noori A, Piggott T, Qiu Y, Roldan Y, Schünemann F, Stevens A, Solo K, Ventresca M, Wiercioch W, Mustafa RA, Schünemann HJ (2021) American Society of Hematology 2021 guidelines on the use of anticoagulation for thromboprophylaxis in patients with COVID-19. Blood Adv 5(3):872-888. https://doi.org/10.1182/ bloodadvances. 2020003763

Publisher's note Springer Nature remains neutral with regard to jurisdictional claims in published maps and institutional affiliations. 